\title{
The Healthy and Diseased Equine Endometrium: Molecular Aspects in the Context of Tissue Morphology
}

\author{
Created by: Sandra Schöniger \\ Version received: 27 April 2020
}

check for updates

\begin{abstract}
Mares are seasonal polyestric. The morphology of the healthy equine endometrium is influenced by the season of the year, the stage of the endometrial cycle, as well as the presence of endometrial diseases. The latter have an impact on the wellbeing of individual mares and can also inflict major financial losses for the horse breeding industry. The microscopic examination of an endometrial biopsy is an important diagnostic tool, since it can also detect subclinical diseases. This review provides an overview about morphological and molecular features of the healthy and diseased equine endometrium. It reviews the diagnostic findings of inflammatory and degenerative endometrial disease of mares, as well as the current state of knowledge regarding their cellular and molecular pathogenesis. It further shows that the comparative evaluation of morphological features and molecular characteristics of the healthy and diseased equine endometrium is an important prerequisite for the identification of disease-associated molecular markers, which in turn will facilitate the development of diagnostic and predictive biomarkers, as well as novel prophylactic and therapeutic options. Although currently numerous molecular data are already available, future studies are required to establish their translation into clinical practice.
\end{abstract}

\section{Overview}

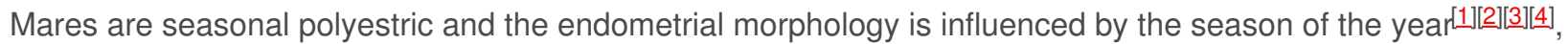
external factors such as lightening and temperature ${ }^{[3]}$ as well as the stage of the endometrial cycle ${ }^{[1][2] .}$

Endometrial diseases of mares are an important cause of subfertility[1][2][5] and can inflict major financial losses for the horse breeding industry. Endometrial diseases include endometrosis (synonym: periglandular fibrosis), endometritis, glandular differentiation disorders, and angiosis (synonym: angiosclerosis) as well as their subtypes [1][2][4][5][6][7]. The concurrent presence of several endometrial diseases in an individual mare is a common finding [1][5]. As a physiological reaction, mating or breeding evokes transient inflammation with a duration of less than 72 hrs [5][8][9]. Some mares, however, develop persisting post-breeding endometritis; these are referred to as "susceptible mares" [9][10].

The microscopic examination of an endometrial biopsy is an important diagnostic tool, since it can detect all types of endometrial diseases including subclinical diseases ${ }^{[5]}$. Moreover, it allows to determine the stage of the endometrial cycle [2][11]. The incidence and degree of some endometrial diseases are influenced by factors of the mare such as age and numbers of parturitions [5][6][7][12]. Microscopic findings in the endometrial biopsy of a mare, however, need to be interpreted under consideration of signalment of the mare, clinical history and season of the year [2][4][5][13].

Based on the detection of certain microscopic findings, i.e. incidence and degree of endometritis, periglandular fibrosis and lymphatic lacunae, as well as endometrial atrophy during the breeding season, together with the length of barrenness, the categorization scheme of Kenney and Doig [1] is used for prognostication of the fertility of an individual mare. Subsequently, glandular maldifferentiation [13][14][15], angiosclerosis [6][13][16], subtype of endometrosis [5][17], older age of the mare ${ }^{[5]}[13]$ and a previous long-term use of the mare in athletic performances ${ }^{[18]}$ have been revealed as further factors of reduced fertility.

The pathogenesis of some endometrial diseases such as nonsuppurative endometritis $[5][19]$ and endometrosis $[5][7][\underline{20}]$ has still not been revealed in detail. No routinely available treatment exists for endometrosis [7][20]. Moreover, nonsuppurative endometritis often persists despite treatment [5] [10] . Notably, endometrial neoplasia is a rare finding in mares [21]. 


\section{Encyclopedia}

diagnostic value and will assist to gain further insights into the molecular pathogenesis of endometrial diseases [15][17][19][22][23][24][25][26][27][28][29][30][31][32]. In addition, they will likely help to design novel prophylactic regimes and treatment options [20]. Certain molecular markers have the be considered as potential biomarkers for equine endometrial health and disease, since they identify morphological and functional cellular alterations associated with endometrial diseases [15][17][23][24][25][26][27][29][30][31][32] and their cellular expression patterns can be visualized and

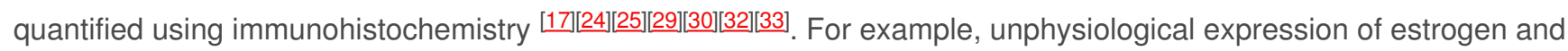
progesterone receptors predicts altered hormonal responsiveness of the equine endometrium [17][24]. Changes in the physiological immunoreaction for intermediate filaments and associated proteins are consistent with an abnormal cellular differentiation [24][31][32]. Deviations in the expression of secretory proteins by glandular epithelia will likely cause alterations in the composition of the uterine milk as essential nutrition of the early equine conceptus [17][25]. Changes in the immunostaining for components of the innate immune defense, i.e. $\beta$-defensin and indoleamine 2,3dioxygenase 1, suggest alterations of endometrial immunity mechanisms [29][30].

\section{Conclusions}

The combined evaluation of morphological findings and associated molecular features indicates that some examined molecular markers have the potential to serve as biomarkers for endometrial health and disease ${ }^{34]}$. A biomarker is a biological parameter that can be objectively evaluated and indicates a normal or abnormal biological process or a response to an intervention, e.g. an immunohistochemical marker with diagnostic or prognostic value or merit for the prediction of a treatment response [35][36].

In the equine endometrium, molecules with potential to serve as biomarkers include estrogen and progesterone receptors, intermediate filaments, secretory proteins and components of the innate immune defense [34]. The comparative assessment of molecular markers within the healthy and diseased equine endometrium will likely help to identify and quantify cellular dysfunctions associated with endometrial diseases and their subtypes ${ }^{[34]}$. Obtained data could assist to more precisely estimate the fertility prognosis of an individual mare $[34$. In addition, they are a prerequisite for the development of novel prophylactic regimes and treatment options [20][34]. Additional studies are required to establish the translation of research data into clinical practice.

The content of this article is summarized in Figure 1.

The healthy and diseased equine endometrium: molecular aspects in the context of tissue morphology

\section{Endometrial diseases of mares}

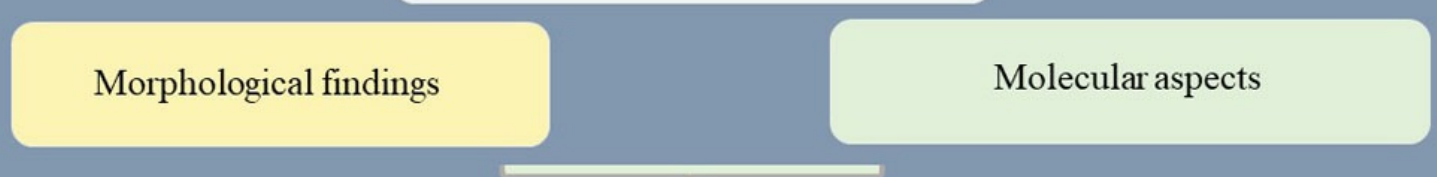

\section{Combined analysis:}

$\rightarrow$ Prerequisite for identification of

- Molecular pathogenesis

- Biomarkers for endometrial health and disease

Possible future clinical applications

Refinement of fertility prognosis

Novel treatment options 


\section{References}

1. K.P. Freeman; J.F. Roszel; S.H. Slusher; M. Castro; Variation in glycogen and mucins in the equine uterus related to physiologic and pathologic conditions. Theriogenology 1990, 33, 799-808, 10.1016/0093-691x(90)90815-b.

2. Schoon, H.-A.; Schoon, D.; Klug, E. Uterusbiopsien als Hilfsmittel für Diagnose und Prognose von Fertilitätsstörungen der Stute. Pferdeheilkunde 1992, 8, 355-362. [Google Scholar] [CrossRef]

3. Schoon, H.-A.; Schoon, D.; Klug, E. Die Endometriumbiopsie bei der Stute im klinisch-gynäkologischen Kontext. Pferdeheilkunde 1997, 13, 453-464. [Google Scholar] [CrossRef]

4. D Schoon; H-A Schoon; E Klug; Angioses in the equine endometrium - Pathogenesis and clinical correlations. Pferdeheilkunde Equine Medicine 1999, 15, 541-546, 10.21836/pem19990610.

5. Schoon, H.-A.; Schoon, D.; Wiegandt, I.; Bartmann, C.-P.; Aupperle, H. "Endometrial maldifferentiation"-A clinically significant diagnosis in equine reproduction? Pferdeheilkunde 1999, 15, 555-559. [Google Scholar] [CrossRef]

6. H A Schoon; I Wiegandt; D Schoon; H. Aupperle; C P Bartmann; Functional disturbances in the endometrium of barren mares: a histological and immunohistological study.. Journal of reproduction and fertility. Supplement 2000, null, , null.

7. Schoon, H.-A.; Schoon, D. The category I mare (Kenney and Doig 1986): Expected foaling rate 80-90\%—Fact or fiction? Pferdeheilkunde 2003, 19, 698-701. [Google Scholar] [CrossRef]

8. J. Buczkowska; Roland Kozdrowski; Marcin Nowak; A. Raś; J. Mrowiec; Endometrosis - significance for horse reproduction, pathogenesis, diagnosis, and proposed therapeutic methods. Polish Journal of Veterinary Sciences 2014, 17, 547-554, 10.2478/pjvs2014-0083.

9. Killisch, R.; Böttcher, D.; Theuß, T.; Edzards, H.; Martinsson, G.; Einspanier, A.; Gottschalk, J.; Schoon, H.-A. Seasonal or pathological findings? Morphofunctional characteristics of the equine endometrium during the autumn and spring transition. Reprod. Dom. Anim. 2017, 52, 1011-1018. [Google Scholar] [CrossRef]

10. Terttu Katila; Onset and Duration of Uterine Inflammatory Response of Mares after Insemination with Fresh Semen. Biology of Reproduction 1995, 52, 515-517, 10.1093/biolreprod/52.monograph_series1.515.

11. M.H.T. Troedsson; Uterine clearance and resistance to persistent endometritis in the mare. Theriogenology 1999, 52, 461-471, 10.1016/s0093-691x(99)00143-0.

12. Michelle M. Leblanc; Rc Causey; Clinical and Subclinical Endometritis in the Mare: Both Threats to Fertility. Reproduction in Domestic Animals 2009, 44, 10-22, 10.1111/j.1439-0531.2009.01485.x.

13. Kilgenstein, H.J.; Schöniger, S.; Schoon, D.; Schoon, H.-A. Microscopic examination of endometrial biopsies of retired sports mares: An explanation for the clinically observed subfertility? Res. Vet. Sci. 2015, 99, 171-179. [Google Scholar] [CrossRef] [PubMed]

14. Lisley I. Mambelli; Rodrigo C. Mattos; Gustavo H. Z. Winter; Dener S. Madeiro; Bruna P. Morais; Eduardo Malschitzky; Maria Angélica Miglino; Alexandre Kerkis; Irina Kerkis; Changes in Expression Pattern of Selected Endometrial Proteins following Mesenchymal Stem Cells Infusion in Mares with Endometrosis. PLOS ONE 2014, 9, e97889, 10.1371/journal.pone.0097889.

15. Aupperle, H.; Steiger, K.; Reischauer, A.; Schoon, H.-A. Ultrastructural and immunohistochemical characterization of the physiological and pathological inactivity of the equine endometrium. Pferdeheilkunde 2003, 19, 629-632. [Google Scholar] [CrossRef]

16. Heike Aupperle; D Schoon; H.-A Schoon; Physiological and pathological expression of intermediate filaments in the equine endometrium. Research in Veterinary Science 2004, 76, 249-255, 10.1016/j.rvsc.2003.11.003.

17. S Schöniger; H Gräfe; H-A Schoon; Beta-defensin is a component of the endometrial immune defence in the mare. Pferdeheilkunde Equine Medicine 2013, 29, 335-346, 10.21836/pem20130307.

18. N Huth; S Schöniger; H Sieme; C P Bartmann; H A Schoon; Lymphocyte subpopulations in the equine endometrium: a methodical approach with diagnostic implications. Pferdeheilkunde Equine Medicine 2014, 30, 4-14, 10.21836/pem20140101.

19. Rebordão; Antonio M. Galvao; Anna Szóstek-Mioduchowska; Ana Amaral; Luísa Mateus; Dariusz J. Skarzynski; Graça Maria Leitão Ferreira Dias; Physiopathologic Mechanisms Involved in Mare Endometrosis. Reproduction in Domestic Animals 2014, 49, 82-87, 10.1111/rda.12397.

20. K Klose; H-A Schoon; Periglandular inflammatory cells in the endometrium of the mare - A physiological defence mechanism which impacts on the development of endometrosis?. Pferdeheilkunde Equine Medicine 2016, 32, 15-23, 10.21836/pem20160102.

21. S Schöniger; D Böttcher; T. Theuß; H Gräfe; H-A Schoon; New insights into the innate immune defences of the equine endometrium: in situ and in vitro expression pattern of beta-defensin. Pferdeheilkunde Equine Medicine 2016, 32, 4-14, 10.21836/pem20160101.

22. Rudolph, N.; Schoon, H.-A.; Schöniger, S. Immunohistochemical characterization of immune cells in fixed equine endometrial tissue: A diagnostic relevant method. Pferdeheilkunde 2017, 33, 524-537. [Google Scholar] [CrossRef]

23. Sandra Schöniger; Hilke Gräfe; Heinz-Adolf Schoon; Expression of Toll-like receptors 2, 4 and 6 in different cell populations of the equine endometrium. Veterinary Immunology and Immunopathology 2017, 185, 7-13, 10.1016/j.vetimm.2017.01.002.

24. Sandra Schöniger; Denny Böttcher; Tobias Theuß; Heinz-Adolf Schoon; Expression of Toll-like receptors 2, 4 and 6 in equine endometrial epithelial cells: A comparative in situ and in vitro study. Research in Veterinary Science 2017, 112, 34-41, 10.1016/j.rvsc.2017.01.004.

25. Sandra Schöniger; Hilke Gräfe; Franziska Richter; Heinz-Adolf Schoon; Expression of indoleamine 2,3-dioxygenase 1 as transcript and protein in the healthy and diseased equine endometrium. Research in Veterinary Science 2018, 118, 278-287, 10.1016/j.rvsc.2018.03.001. 
26. Schöniger, S.; Gräfe, H.; Schoon, H.-A. Innate immunity mechanisms of the equine endometrium—Benefit or harm? Pferdeheilkunde 2018, 34, 5-11. [Google Scholar] [CrossRef]

27. Bischofberger, L.; Szewczyk, K.; Schoon, H.-A. Unequal glandular differentiation of the equine endometrium-A separate endometrial alteration? Pferdeheilkunde 2019, 35, 304-315. [Google Scholar] [CrossRef]

28. Claudia Minkwitz; Heinz-Adolf Schoon; Qian Zhang; Sandra Schöniger; Plasticity of endometrial epithelial and stromal cells-A new approach towards the pathogenesis of equine endometrosis.. Reproduction in Domestic Animals 2019, 54, 835-845,

10.1111/rda.13431.

29. Rowan E. Moore; Jennifer A. Kirwan; Mary Doherty; Phillip D. Whitfield; Biomarker Discovery in Animal Health and Disease: The Application of Post-Genomic Technologies. Biomarker Insights 2007, 2, 185-196, 10.1177/117727190700200040.

30. J D Groopman; G N Wogan; Bill D. Roebuck; T W Kensler; Molecular biomarkers for aflatoxins and their application to human cancer prevention.. Cancer Research 1994, 54, , null.

31. Clive R. Taylor; Introduction to Predictive Biomarkers: Definitions and Characteristics. Predictive Biomarkers in Oncology 2018, null, 3-18, 10.1007/978-3-319-95228-4_1.

32. Sidney W. Ricketts; The Technique and Clinical Application of Endometrial Biopsy in the Mare. Equine Veterinary Journal 1975, 7 , 102-108, 10.1111/j.2042-3306.1975.tb03243.x.

33. R M Kenney; Cyclic and pathologic changes of the mare endometrium as detected by biopsy, with a note on early embryonic death.. Journal of the American Veterinary Medical Association 1978, 172, , null.

34. C Aurich; C Maric; J Aurich; The interpretation of endometrial biopsies in mares - a retrospective study. Pferdeheilkunde Equine Medicine 2011, 27, 281-286, 10.21836/pem20110313.

35. W. R. Allen; S. Wilsher; Half a century of equine reproduction research and application: A veterinarytour de force. Equine Veterinary Journal 2017, 50, 10-21, 10.1111/evj.12762.

36. Brunckhorst, D.; Schoon, H.-A.; Bader, H.; Sieme, H. Morphologische, enzyme- and immunhistologische Charakteristika des endometrialen Zyklus der Stute. Fertilität 1991, 7, 44-51. [Google Scholar]

\section{Keywords}

Equine; Endometrium; Health; Disease; Pathophysiology; Molecular Features; Mare; Endometrial biopsy

(C) 2020 by the author(s). Distribute under a Creative Commans CC BY license 